\title{
EXERCÍCIO FÍSICO E MELATONINA PROMOVEM CONJUNTAMENTE REDUÇÃO DA ADIPOSIDADEEM RATOS, EMBORA ESTES SE TORNEM HIPOGONÁDICOS
}

Tese apresentada ao Programa de PósGraduação em Fisiologia Humana do Instituto de Ciências Biomédicas da Universidade de São Paulo para obtenção do Título de Doutor em Ciências.

Área de concentração: Fisiologia Humana

Orientador: Prof. Dr. Fábio Bessa Lima

Versão original 


\section{RESUMO}

Proença ARG. Exercício físico e melatonina promovem conjuntamente redução da adiposidade em ratos, embora estes se tornem hipogonádicos. [tese (Doutorado em Fisiologia Humana)]. São Paulo: Instituto de Ciências Biomédicas, Universidade de São Paulo; 2013.

$\mathrm{Na}$ última década, vários estudos observaram que a melatonina, além de alterar o peso corporal de animais, também reduz adiposidade e melhora a sensibilidade à insulina no tecido adiposo. Entretanto, alguns trabalhos apontam um possível efeito antigonadotrófico da melatonina. Em relação ao exercício físico, suas contribuições no controle do peso corporal assim como da adiposidade já foram evidenciadas por diversos estudos. Dessa forma, o objetivo deste trabalho foi o de averiguar se o exercício físico somado a suplementação com melatonina em animais pós-púberes, modifica a adiposidade e a regulação da atividade lipolítica, nos tecidos adiposos localizados nas regiões subcutânea inguinal (SUB) e retroperitoneal (RP), além de verificar possíveis efeitos antigonadotróficos decorrentes do tratamento com melatonina. A concomitância do treinamento físico (50-60\% da capacidade máxima) e da suplementação com melatonina $(0,2 \mathrm{mg} / \mathrm{Kg} / \mathrm{dia})$ durante 8 semanas em ratos Wistar de 11 semanas de idade foi mais eficiente em promover reduções no diâmetro dos adipócitos e, consequentemente, na adiposidade do que o uso isolado do treinamento físico ou da suplementação com melatonina. Entretanto, não foram observadas alterações na atividade lipolítica, e nem na lipogênese, medidas em adipócitos isolados das regiões estudadas. Foi demonstrado também que, mesmo em doses reduzidas, a suplementação promoveu hipogonadismo com consequente redução da testosteronemia, além de uma redução da massa do músculo EDL (de contração rápida), evidenciando assim a necessidade de se aprofundar os estudos sobre os impactos do uso de melatonina sobre o eixo hipófise-hipotálamo-gônadas.

Palavras-chave: Treinamento físico. Melatonina. Adiposidade. Lipólise. Hipogonadismo. 


\begin{abstract}
Proença ARG. Exercise and melatonin acting together promote in rats adiposity reduction, although they become hypogonadic. [Ph. D. thesis (Human Phisiology)]. São Paulo: Instituto de Ciências Biomédicas, Universidade de São Paulo; 2013.

In the last decade, several studies showed that melatonin, besides changing body weight of animal also reduces adiposity and improves insulin sensitivity in adipose tissue. However, some of them pointed to a possible melatonin's antigonadotropic action. In relation to exercise, its contributions to the control of body weight, as well as adiposity, have been highlighted by several studies. Hence, the purpose of this study was to investigate whether the physical exercise plus supplementation with melatonin in postpubertal animals modify adiposity and regulation of lipolysis in the inguinal subcutaneous (SUB) and retroperitoneal (RP) adipose tissues, away from assessing the possible antigonadotropic effects resulting from melatonin treatment. The concomitance of physical training (50-60\% maximum) and melatonin supplementation $(0.2 \mathrm{mg} / \mathrm{kg} /$ day) for 8 weeks to 11 weeks old rats were more efficient in promoting reductions in adipocyte size and hence in adiposity than physical training or melatonin supplementation alone. However, no changes were observed in lipolysis or in lipogenesis, measured in isolated adipocytes from investigated the fat depots. We also showed that, even at this low dose, melatonin promoted hypogonadism with consequent reduction of the testosteronemia and a reduction in EDL (extensor digitorum longus) muscle mass (fast twitch), thus evidencing that further studies on the impacts of the use of melatonin the hypothalamic-pituitary-gonadal axis are actually needed.
\end{abstract}

Keywords: Physical training. Melatonin. Adiposity. Lipolisys. Hypogonadism. 


\section{INTRODUÇÃO}

O tecido adiposo (TA) é o maior reservatório de energia de que dispomos, sendo durante muito tempo considerado um tecido cuja finalidade era apenas esta. $\mathrm{Na}$ última década do século passado, descobriu-se que, além de ser abundante fonte de energia, o TA era também um importante produtor de substâncias biologicamente ativas, passando então a ser reconhecido como órgão endócrino, desempenhando um papel ativo na regulação do metabolismo energético ${ }^{1,2}$.

O interesse por seu estudo mais aprofundado se deveu, em parte, ao aumento epidêmico da obesidade nas mais diversas sociedades contemporâneas. A combinação de hábitos alimentares constituídos por dietas ricas em gorduras e açucares e o sedentarismo é responsável pelo número crescente de pessoas com sobrepeso e obesidade, sendo hoje um dos maiores problemas de saúde no mundo ocidental, atingindo, em certos casos, um terço da população ${ }^{3,4,5,6}$.

Este fato fez com que houvesse maior necessidade de pesquisas que possibilitassem melhor entendimento da funcionalidade do tecido adiposo. Estudos in vivo e in vitro realizados tanto em animais como em humanos, uso de técnicas como microdiálise, assim como avanços na área da biologia molecular culminaram em maior entendimento a respeito da fisiologia do tecido adiposo. Estes estudos, além de buscarem elucidar aspectos e fatores que interferem no controle metabólico como dieta, exercício, patologias, idade, fármacos, estresse, etc, procuram ainda entender o reflexo de um aumento ou de uma diminuição da adiposidade, localizada ou generalizada no organismo como um todo.

As duas principais ações metabólicas do tecido adiposo branco são a lipólise (mobilização ou hidrólise do triacilglicerol) e lipogênese (armazenamento ou síntese de ácidos graxos). A importância dessas ações conferiu ao tecido adiposo papel fundamental no controle metabólico ${ }^{7}$. Tanto a lipólise como a lipogênese são reguladas pela integração dos mecanismos endócrino e neural, que cooperam para manter a massa adiposa relativamente constante frente às condições habituais. Inúmeros trabalhos científicos já evidenciaram o reflexo do exercício físico no metabolismo energético, e principalmente sua contribuição na redução ou na contenção de um aumento da adiposidade.

Nas duas últimas décadas, pesquisadores passaram a demonstrar uma considerável participação na melatonina no metabolismo energético. Alguns 
trabalhos evidenciaram sua influência na regulação da adiposidade. Entretanto, ainda há perguntas a serem respondidas sobre os impactos, positivos e negativos que seu uso, na reposição ou no tratamento, pode causar ao organismo. Devido ao fato de alguns estudos, citados posteriormente, demonstrarem um efeito central desse hormônio com repercussões gonádicas, adotamos o modelo animal de suplementação com melatonina, objetivando avaliar os efeitos no metabolismo do adipócito, assim como nas estruturas que compõem o sistema reprodutor. 


\section{CONCLUSÃO}

Concluímos que, além das repercussões isoladas de cada intervenção, o uso concomitante do treinamento físico $(50-60 \%$ da capacidade máxima) e da suplementação com melatonina $(0,2 \mathrm{mg} / \mathrm{Kg} / \mathrm{dia})$ durante 8 semanas em ratos Wistar de 11 semanas de idade, foi mais eficiente em promover reduções no diâmetro dos adipócitos e, consequentemente, na adiposidade do que o uso isolado do treinamento físico ou da suplementação com melatonina. Entretanto, não foram observadas alterações na atividade lipolítica, e nem na lipogênese, medidas em adipócitos isolados das regiões subcutânea inguinal e retroperitoneal.

Este trabalho reforça também que há uma necessidade em aprofundar os estudos sobre os impactos do uso de melatonina no eixo hipófise-hipotálamogônadas, uma vez que, mesmo em doses reduzidas, a suplementação promoveu hipogonadismo, com consequente redução da testosteronemia, além de uma redução da massa do músculo EDL. 


\section{REFERÊNCIAS*}

1. Ahima RS, Flier JS. Adipose tissue as an endocrine organ. Trends Endocrinol Metab. 2000;11:327-32.

2. Fruhbeck G, Gomez-Ambrosi J, Muruzabal FJ, Burrell MA. The adipocyte: a model for integration of endocrine and metabolic signaling in energy metabolism regulation. Am J Physiol Endocrinol Metab. 2001;280: 827-47.

3. Bouchard C. Obesidade e Atividade Física. São Paulo: Manole; 2003.

4. World health organization. Obesity - preventing and managing the global epidemic. Report of a WHO consultation on obesity. Geneva: World Health Organization; 1998.

5. Monteiro CA. Epidemiologia da obesidade. In: Halpern A, et al. Obesidade. São Paulo: Lemos Editorial; 1998. p. 15-30.

6. $\quad$ Eloi R. Livre do "pesadelo" da obesidade mórbida. Mídia \& Saúde; 2002. vol. 1, p. 16-17.

7. Fonseca-Alaniz MH, Takada J, Alonso-Vale MI, Lima FB. O Tecido Adiposo Como Centro Regulador do Metabolismo. Arq Bras Endocrinol Metab. 2006;50.

8. Goodman JM. Demonstrated and inferred metabolism associated with cytosolic lipid droplets. J Lipid Res. 2009;50:2148-56.

9. Langin D, Lafontan M. Lipolysis and lipid mobilization in human adipose tissue. In: Bray GA, Bouchard C, editors. Handbook of obesity. Etiology and pathophysiology. 2nd ed. New York: M Dekker; 2004. p. 515-32.

10. Sengenes C, Berlan M, de Glisezinski I, Lafontan M, Galitzky J. Natriuretic peptides: a new lipolytic pathway in human adipocytes. FASEB J. 2000;14:1345-51.

11. Gravholt $\mathrm{CH}$, Schmitz O, Simonsen L, Bülow J, Christiansen JS, Moller N. Effects of a physiological GH pulse on interstitial glycerol in abdominal and femoral adipose tissue. Am J Physiol. 1999;277:E848-54.

12. Heffernan MA, Jiang WJ, Thorburn AW, Ng FM. Effects of oral administration of a synthetic fragment of human growth hormone on lipid metabolism. Am J Physiol 2000; 279:E501-07.

\footnotetext{
*De acordo com: International Committee of Medical Journal Editors. Uniform requirements for manuscripts submitted to Biomedical Journal: sample references. [2011 July 15]. Available from: http://www.icmje.org
}

13. Gasic S, Tian B, Green A. Tumor necrosis factor alpha stimulates lipolysis in adipocytes by decreasing Gi protein concentrations. J Biol Chem. 1999;274:6770-5. 
14. Ryden M, Dicker A, Van Harmelen V, et al. Mapping of early signalling events

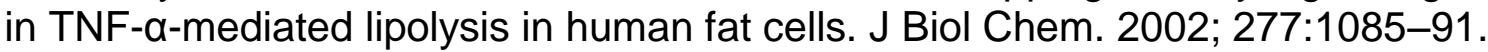

15. Lafontan M. Fat cells: Afferent and efferent messages define new approaches to treat obesity. Annu Rev Pharmacol Toxicol. 2005;45:119-46.

16. Campbell JE, Peckett AJ, D'souza AM, Hawke TJ, Riddell MC. Adipogenic and lipolytic effects of chronic glucocorticoid exposure. Am J Physiol Cell Physiol. 2011; 300:C198-209.

17. Xu C, He J, Jiang H, Zu L, Zhai W, Pu S, Xu G: Direct effect of glucocorticoids on lipolysis in adipocytes. Mol Endocrinol. 2009;23:1161-70.

18. Kiwaki K, Levine JA. Differential effects of adrenocorticotropic hormone on human and mouse adipose tissue. J Comp Physiol B. 2003;173:675-8.

19. Lafontan $\mathrm{M}$, Berlan $\mathrm{M}$. Fat cell adrenergic receptors and the control of white and brown fat cell function. J Lipid Res. 1993;34:1057-91.

20. Langin D. Adipose tissue lipolysis as a metabolic pathway to define pharmacological strategies against obesity and the metabolic syndrome. Pharmacol Res. 2006;53:482-91.

21. Oka Y, Saraiva LR, Kwan YY, Korshing SI. The fifth class of G_proteins. Proc Natl Acad Sci USA. 2009;106:1484-9.

22. Lafontan M, Berlan M. Fat cell a2-adrenoceptors: the regulation of fat cell function and lipolysis. Endocrine Rev. 1995;16: 716-38.

23. de Glisezinski I, Larrouy D, Bajzova M, et al. Adrenaline but not noradrenaline is a determinant of exercise-induced lipid mobilization in human subcutaneous adipose tissue. J Physiol-London. 2009;587:3393-404.

24. Silva BV, Horta BAC, Alencastro RB, et al. Proteínas quinases: características estruturais e inibidores químicos. Quim Nova. 2009;32:453-62.

25. Anthonsen MW, Rönnstrand L, Wernstedt C, Degerman E, Holm C. Identification of novel phosphorylation sites in hormone-sensitive lipase that are phosphorylated in response to isoproterenol and govern activation properties in vitro. J Biol Chem.1998; 273:215-21.

26. Shen WJ, Liang Y, Hong R, Patel S, Natu V, Sridhar K, et al. Characterization of the functional interaction of adipocyte lipid-binding protein with hormone sensitive lipase. J Biol Chem. 2001;276:49443-8.

27. Lampidonis AD, Rogdakis E, Voutsinas GE, Stravopodis DJ. The resurgence of Hormone-Sensitive Lipase (HSL) in mammalian lipolysis. Gene. 2011;477:1-11. 
28. Okazaki H, Osuga J, Tamura $\mathrm{Y}$, et al. Lipolysis in the absence of hormonesensitive lipase: evidence for a common mechanism regulating distinct lipases. Diabetes. 2002;51:3368-75.

29. Haemmerle G, Zimmermann R, Hayn M, et al. Hormone-sensitive lipase deficiency in mice causes diglyceride accumulation in adipose tissue, muscle, and testis. J Biol Chem. 2002;277:4806-15.

30. Lass A, Zimmermann R, Oberer M, Zechner R. Lipolysis-a highly regulated multi-enzyme complex mediates the catabolism of cellular fat stores. Progress in Lipid Research. 2011;50:14-27.

31. Xu L, Zhou L, Li P CIDE Proteins and lipid metabolism. Arterioscler Thromb Vasc Biol. 2012; 32:1094-8.

32. Sztalryd C, Xu G, Dorward H, et al. Perilipin A is essential for the translocation of hormone-sensitive lipase during lipolytic activation. J Cell Biol. 2003;161:1093103.

33. Vigouroux C, Caron-Debarle M, Le Dour C, Magré J, Capeau J. Molecular mechanisms of human lipodystrophies: From adipocyte lipid droplet to oxidative stress and lipotoxicity. Int J Biochem Cell Biol. 2011;43:862-76.

34. Zimmermann R, Strauss JG, Haemmerle G, et al. Fat mobilization in adipose tissue is promoted by adipose triglyceride lipase. Science 2004;306:1383-86.

35. Zechner R, Kienesberger PC, Haemmerle G, Zimmermann R, Lass A. Adipose triglyceride lipase and the lipolytic catabolism of cellular fat stores. J Lipid Res. 2009;50:3-21.

36. Haemmerle G, Lass A, Zimmermann R, et al. Defective lipolysis and altered energy metabolism in mice lacking adipose triglyceride lipase. Science. 2006;312: 734-7.

37. Lass A, Zimmermann R, Haemmerle G, et al. Adipose triglyceride lipasemediated lipolysis of cellular fat stores is activated by CGI-58 and defective in Chanarin-Dorfman syndrome. Cell Metab 2006; 3: 309-19.

38. Subramanian V, Rothenberg A, Gomez C, et al. Perilipin A mediates the reversible binding of CGI-58 to lipid droplets in 3T3-L1 adipocytes. J Biol Chem. 2004; 279:42062-71.

39. Granneman JG, Moore HP, Granneman RL, Greenberg AS, Obin MS, Zhu Z. Analysis of lipolytic protein trafficking and interactions in adipocytes. J Biol Chem. 2007;282:5726-35

40. Nishino N, Tamori Y, Tateya S, Kawaguchi T, Shibakusa T, Mizunoya W, et al. FSP27 contributes to efficient energy storage in murine white adipocytes by promoting the formation of unilocular lipid droplets. J Clin Invest. 2008;118:2808-21. 
41. Yang $X$, Heckmann BL, Zhang $X$, Smas CM, Liu J. Distinct mechanisms regulate ATGL-mediated adipocyte lipolysis by lipid droplet coat proteins. Mol Endocrinol. 2013;27(1):116-26.

42. Yang $X$, Lu X, Lombès $M$, Rha GB, Chi YI, Guerin TM, Smart EJ, Liu J. The $\mathrm{G}(0) / \mathrm{G}(1)$ switch gene 2 regulates adipose lipolysis through association with adipose triglyceride lipase. Cell Metab. 2010;11(3):194-205.

43. Lafontan $M$, Langin D. Lipolysis and lipid mobilization in human adipose tissue. Prog Lipid Res. 2009;48:275-97.

44. Fredrikson G, Tornqvist $\mathrm{H}$, Belfrage $\mathrm{P}$. Hormone-sensitive lipase and monoacylglycerol lipase are both required for complete degradation of adipocyte triacylglycerol. Biochim Biophys Acta. 1986; 876:288-93.

45. Shen WJ, Sridhar K, Bernlohr DA, Kraemer FB. Interaction of rat hormonesensitive lipase with adipocyte lipidbinding protein. Proc Natl Acad Sci USA. 1999; 96:5528-32.

46. Hamilton JA, Kamp F. How are free fatty acids transported in membranes? Is it by proteins or by free diffusion through the lipids?. Diabetes. 1999;48:2255-69.

47. Langin D. Control of fatty acid and glycerol release in adipose tissue lipolysis.C R Biol. 2006;329:598-607.

48. Tansey JT, Sztalryd C, Hlavin EM, Kimmel AR, Londos C. The central role of perilipin A in lipid metabolism and adipocyte lipolysis. IUBMB Life. 2004;56:379-85.

49. King LS, Kozono D, Agre P. From structure to disease: the evolving tale of aquaporin biology. Nat Rev Mol Cell Biol. 2004;5:687-98.

50. Hibuse T, Maeda N, Funahashi T, et al. Aquaporin 7 deficiency is associated with development of obesity through activation of adipose glycerol kinase. Proc Natl Acad Sci USA. 2005;102:10993-8.

51. Maeda N, Funahashi T, Hibuse T, et al. Adaptation to fasting by glycerol transport through aquaporin 7 in adipose tissue. Proc Natl Acad Sci USA. 2004;101: 17801-6.

52. Hara-Chikuma M, Sohara E, Rai T, et al. Progressive adipocyte hypertrophy in aquaporin-7-deficient mice: adipocyte glycerol permeability as a novel regulator of fat accumulation. J Biol Chem. 2005;280:15493-6.

53. Hanson RW, Reshef L. Glyceroneogenesis revisited. Biochimie. 2003;85:1199-205.

54. Jensen MD, Ekberg K, Landau BR. Lipid metabolism during fasting. Am J Physiol Endocrinol Metab. 2001;281:E789. 
55. Nye CK, Hanson RW, Kalhan SC.Glyceroneogenesis Is the Dominant Pathway for Triglyceride Glycerol Synthesis in Vivo in the Rat. J Biol Chem. 2008;283:27565-74.

56. Ballard FJ, Hanson RW, Leveille GA. Phosphoenolpyruvate carboxykinase and the synthesis of glyceride-glycerol from pyruvate in adipose tissue. J Biol Chem. 1967;242:2746-50.

57. Festuccia WT, Guerra-Sa R, Kawashita NH, et al. Expression of glycerokinase in brown adipose tissue is stimulated by the sympathetic nervous system. Am J Physiol Regul Integr Comp Physiol. 2003;284:R1536-41.

58. Chen JL, Peacock E, Samady WT, et al. Physiologic and pharmacologic factors influencing glyceroneogenic contribution to triacylglycerides glycerol measured by mass isotopomer distribution analysis. J Biol Chem. 2005;280:25396402.

59. Brito SC, Festuccia WL, Kawashita NH, et al. Increased glyceroneogenesis in adipose tissue from rats adapted to a high-protein, carbohydrate-free diet: role of dietary fatty acids. Metabolism. 2006;55:84-9.

60. Nye CK, Hanson RW, Kalhan SC. Glyceroneogenesis is the dominant pathway for triglyceride glycerol synthesis in vivo in the rat. $\mathrm{J}$ Biol Chem. 2008;283:27565-74.

61. Jensen MD: Lipolysis: contribution from regional fat. Annu Rev Nutr. 1997;17:127-39.

62. Rebuffe-Scrive M, Andersson B, Olbe L, Bjorntorp P: Metabolism of adipose tissue in intraabdominal depots of nonobese men and women. Metabolism. 1989; 38:453-58.

63. Vikman HL, Savola JM, Raasmaja A,Ohisalo JJ: Alpha 2A-adrenergic regulation of cyclic AMP accumulation and lipolysis in human omental and subcutaneous adipocytes. Int J Obes Relat Metab Disord. 1996; 20:185-(9).

64. Portillo MP, Villaro JM, Torres MI,Macarulla MT: In vivo lipolysis in adipose tissue from two anatomical locations measured by microdialysis. Life Sci. 2000; 67:437-45.

65. Palou M, Priego T, Sánchez J, Rodríguez AM, Palou A, Picó C. Gene expression patterns in visceral and subcutaneous adipose depots in rats are linked to their morphologicfeatures. Cell Physiol Biochem. 2009;24(5-6):547-56.

66. Gustat J, Srinivasan SR ,Elkasabany A, Berenson GS. Relation of self-rated measures of physical activity to multiple risk factors of insulin resistance síndrome in young adults: the Bogalusa Herat study. J Clin Epide. 2002;55:997-1006.

67. Mcclelland GB. Fat to the fire: The regulation of lipid oxidation with exercise and environmental stress. Comparative Biochem and Physiol. 2004;139:443-60. 
68. Bonifácio NP, César TB. Metabolismo dos lípides durante o exercicio físico. R Bras Ci e Mov. 2005;13(4):101-6.

69. Horowitz JF. Fatty acid mobilization from adipose tissue during exercise. Trends Endocrinol Metab. 2003;14:386-92.

70. Horowitz JF, Mora-Rodriguez R, Byerley LO, Coyle EF. Lipolytic suppression following carbohydrate ingestion limits fat oxidation during exercise. Am $\mathrm{J}$ Physiol. 1997;273:768-75.

71. Klein S, Coyle EF, Wolfe RR. Fat metabolism during low-intensity exercise in endurance trained and untrained men. Am J Physiol.1994;267:934-40.

72. Wolfe RR, Klein S, Carraro F, Weber JM. Role of triglyceride-fatty acid cycle in controlling fat metabolism in humans during and after exercise. Am J Physiol.1990; 258:382-E38.

73. Romijn JA, Coyle EF, Sidossis LS, Gastaldelli A, Horowitz JF, Endert E, Wolfe RR. Regulation of endogenous fat and carbohydrate metabolism in relation to exercise intensity. Am J Physiol. 1993;265:380-91.

74. Romijn JA, Coyle EF, Sidossis LS, Zhang XJ, Wolfe RR. Relationship between fatty acid delivery and fatty acid oxidation during strenuous exercise. J Appl Physiol. 1995;79:1939-45.

75. Bouchard C, Deprés JP, Tremblay A. Exercise and obesity. Obesity Res. 1993;1:133-47.

76. King NA, Burley VJ, Blundell JE. Exercise- induced suppression of appetite. Effect on food intake and implication for energy balance. Eur $J$ Clin Nutr. 1994;48:715-24.

77. Deprés JP. Obesity regional adipose tissue distribution effect of exercise. Japan Scien Soc Press. 1991;251-9.

78. Ciolac EG, Guimarães GV. Exercício físico e síndrome metabólica. Rev Brás de Méd do Esp. 2004;10:4.

79. Douen AG, Ramlal T, Cartee GD, Klip A. Exercise modulates the insulininduced translocation of glucose transporters in rat skeletal muscle. FEBS Lett. 1990;261:256-60.

80. O'Doherty RM, Bracy DP, Osawa H, Wasserman DH, Granner DK. Rat skeletal muscle hexokinase II mRNA and activity are increased by a single bout of acute exercise. Am J Physiol. 1994;266:E171-8.

81. Ebeling P, Bourey R, Koranyi L, Tuominen JA, Groop LC, Henriksson J, Mueckler M, Sovijarvi A, Koivisto VA. Mechanism of enhanced insulin sensitivity in athletes: increased blood flow, muscle glucose transport protein (GLUT-4) concentration and glycogen synthase activity. J Clin Invest. 1993;92:1623-31. 
82. Stich V, de Glisezinski I, Berlan M, Bulow J, Galitzky J, Harant I, et al. Adipose tissue lipolysis is increased during a repeated bout of aerobic exercise. J Appl Physiol. 2000;88:1277-83.

83. Ruderman NB, Keller C, Richard AM, Saha AK, Luo Z, Xiang X, et al. Interleukin-6 regulation of AMP-activated protein kinase. Potential role in the systemic response to exercise and prevention of the metabolic syndrome. Diabetes. 2006;55(Suppl 2):S48-54.

84. Ruderman NB, Park H, Kaushik VK, Dean D, Constant S, Prentki M, Saha AK. AMPK as a metabolic switch in rat muscle, liver and adipose tissue after exercise. Acta Physiol Scand. 2003;178(4):435-42.

85. Nachbar RT, Proença ARG, Almeida FN, Masi LN, Natali MRM, Costa CEM, Moraes SMF. Efeito da dieta de cafeteria na indução de esteatose hepática em ratos treinados e sedentários. Rev da Educ Fís. 2007;18:85-9.

86. Negrao CE, Moreira ED, Santos MC, Farah VM, Krieger EM. Vagal function impairment after exercise training. J Appl Physiol. 1992;72:1749-53.

87. Claustrat B, Brun J, Chazot G. The basic physiology and pathophysiology of melatonin. Sleep Med Rev. 2005;9:11-24.

88. Lack LC, Wright HR. Chronobiology of sleep in humans. Cell Mol Life Sci. 2007;64:1205-15.

89. Armstrong SM. Melatonin and circadian control in mammals. Experientia. $1989 ; 45(10): 932-8$

90. Cipolla-neto J, Afeche SC. Glandula pineal. In: Aires MM editor. Fisiologia. Rio de Janeiro: Guanabara-Koogan; 1999. p. 805-11.

91. Cagnacci A. Melatonin in relation to physiology in adult humans. J Pineal Res. 1996;21(4):200-13.

92. Cardinali DP, Golombek DA, Rosenstein RE, Cutrera RA, Esquifino AI. Melatonin site and mechanism of action: single or multiple? J Pineal Res. 1997 Aug;23(1):32-9.

93. Becker-Andre M, Wiesenberg I, Schaeren-Wiemers N, Andre E, Missbach M, Saurat $\mathrm{JH}$, Carlberg $\mathrm{C}$. Pineal gland hormone melatonin binds and activates an orphan of the nuclear receptor superfamily. J Biol Chem 1994 269:28531-4.

94. Carlberg C, Wiesenberg I. The orphan receptor family RZR/ROR, melatonin and 5-lipoxygenase: an unexpected relationship. J Pineal Res. 1995 May;18(4):1718.

95. Tan DX, Chen LD, Poegeller B, Manchester LC. Melatonin: a potent, endogenous hydroxyl radical scavenger. Endocr J. 1993;1:57-60. 
96. Tan DX, Manchester LC, Fuentes-Broto L, Paredes SD, Reiter RJ. Significance and application of melatonin in the regulation of brown adipose tissue metabolism: relation to human obesity. Obes Rev. 2011;12(3):167-88.

97. Reiter RJ, Tan DX, Manchester LC, Paredes SD, Mayo JC, Sainz RM. Melatonin and reproduction revisited. Biol Reprod. 2009;81(3):445-56.

98. Lima FB, Machado UF, Bartol I, et al. Pinealectomy causes glucose intolerance and decreases adipose cell responsiveness to insulin in rats. Am J Physiol. 1998;275:934-41.

99. Alonso-Vale MI, Borges-Silva CN, Anhê GF, et al. Light/dark cycle-dependent metabolic changes in adipose tissue of pinealectomized rats. Horm Metab Res. 2004;36:474-9.

100. Ia Fleur SE, Kalsbeek A, Wortel J, van der Vliet J, Buijs RM. Role for the Pineal and Melatonin in Glucose Homeostasis: Pinealectomy Increases Night-Time Glucose Concentrations. J Neuroendocrinol. 2001;13:1025-32.

101. Picinato MC, Haber EP, Carpinelli AR, Cipolla-Neto J. Daily rhythm of glucoseinduced insulin secretion by isolated islets from intact and pinealectomized rats. J Pineal Res. 2002;33:172-7.

102. Borges-Silva CN, Alonso-Vale MI, Franzói-De-Moraes SM, et al. Pinealectomy impairs adipose tissue adaptability to exercise in rats. J Pineal Res. 2005;38:278-83.

103. Puchalski SS, Green JN, Rasmussen DD. Melatonin effect on rat body weight regulation in response to high-fat diet at middle age. Endocrine. 2003;21(2):163-7.

104. Rasmussen DD, Mitton DR, Larsen SA, Yellon SM. Aging-dependent changes in the effect of daily melatonin supplementation on rat metabolic and behavioral responses. J. Pineal Res. 2001;31:89-94.

105. Borges-Silva CN, Fonseca-Alaniz MH, Alonso-Vale MI, et al. Reduced lipolysis and increased lipogenesis in adipose tissue from pinealectomized rats adapted to training. J Pineal Res. 2005;39:178-84.

106. Wolden-Hanson T, Mitton DR, McCants $R L$, et al. Daily melatonin administration to middle-aged male rats suppresses body weight, intra-abdominal adiposity, and plasma leptin and insulin independent of food intake and total body fat. Endocrinology. 2000;141:487-97.

107. Zalatan F, Krause JA, Blask DE. Inhibition of isoproterenol-induced lipolysis in rat inguinal adipocytes in vitro by physiological melatonin via a receptor- mediated mechanism. Endocrinology. 2001;142:3783-90.

108. $\mathrm{Ng} \mathrm{TB}$, Wong CM. Effects of pineal indoles and arginine vasotocin on lipolysis and lipogenesis in isolated adipocytes. J Pineal Res. 1986;3:55-66. 
109. de Oliveira AC, Andreotti S, Farias TS, et al. Metabolic Disorders and Adipose Tissue Insulin Responsiveness in Neonatally STZ-Induced Diabetic Rats Are Improved by Long-Term Melatonin Treatment. Endocrinology. 2012;153(5).

110. Leitner C, Bartness TJ. An intact dorsomedial hypothalamic nucleus, but not the subzona incerta or reuniens nucleus, is necessary for short-day melatonin signalinduced responses in Siberian hamsters. Neuroendocrinology. 2011;93(1):29-39.

111. Fraietta R, Zylberstejn DS, Esteves SC. Hypogonadotropic Hypogonadism Clinics (São Paulo). 2013;68(1).

112. Chowdhury VS, Yamamoto K, Ubuka T, Bentley GE, Hattori A, Tsutsui K. Melatonin Stimulates the Release of Gonadotropin-Inhibitory Hormone by the Avian Hypothalamus Endocrinology. 2010;151(1):271-80.

113. Jiménez-Aranda $A$, Fernández-Vázquez $G$, Campos $D$, Tassi $M$, VelascoPerez L, Tan DX, Reiter RJ, Agil A. Melatonin induces browning of inguinal white adipose tissue in Zucker diabetic fatty rats. J Pineal Res. 2013 Aug 12. In press.

114. Negrão CE, Moreira ED, Santos MCLM, Farah VMA, Krieger EM. Vagal function impairment after exercise training. J Appl Physiol. 1992;72(5):1749-53.

115. Dufloth DL, Morris M, Michelini LC. Modulation of exercise tachycardia by vasopressin in the nucleus tractus solitarii. Am J Physiol Reg Integr Comp Physiol. 1997;42(4):R1271-82.

116. Rodbell M. Metabolism of Isolated Fat. I. Cells Effects of Hormones on Glucose Metabolism + Lipolysis. J Biol Chem. 1964;239(2)375.

117. Fine JB, DiGirolamo M. A simple method to predict cellular density in adipocyte metabolic incubations. Int J Obes Relat Metab Disord. 1997;21(9):764-68.

118. Dole VP, Meinertz $\mathrm{H}$. Microdetermination of long-chain fatty acids in plasma and tissues. J Biol Chem. 1960;235:2595-9.

119. Lima FB, Matsushita DH, Hell NS, Dolnikoff MS, Okamoto MM, Cipolla-Neto J. The regulation of insulin action in isolated adipocytes. Role of the periodicity of food intake, time of day and melatonin. Braz J Med Biol Res. 1994;27(4):995-1000.

120. Lott JA, Turner K. Evaluation of Trinder's glucose oxidase method for measuring glucose in serum and urine. Clin Chem. 1975;21:1754-60.

121. Matthews DR, Hosker JP, Rudenski AS, Naylor BA, Treacher DF, Turner RC. Homeostasis model assesment, insulin resistance and beta-cell function from fasting plasma glucosa and insulin concentrations in man. Diabetologia. 1985;28(7): 412-29.

122. Almeida FN, Proença ARG, Chimin P, Marçal AC, Bessa-Lima F, Carvalho $C R$. physical exercise and pancreatic islets: acute and chronic actions on insulin secretion. Islets. 2012;4(4):296-301. 
123. Mendes C, Lopes AM, do Amaral FG, Peliciari-Garcia RA, Turati Ade O, Hirabara SM, Scialfa Falcão JH, Cipolla-Neto J. Adaptations of the aging animal to exercise: role of daily supplementation with melatonin. J Pineal Res. 2013;55(3):22939.

124. Zanuto R, Siqueira-Filho MA, Caperuto LC, et al. Melatonin improves insulin sensitivity independently of weight loss in old obese rats. J Pineal Res. 2013; 55(2):156-65.

125. Wahlqvist ML, Hodgson JM, Ng FM, Hsu-Hage BH, Strauss BJ. The role of nutrition in abdominal obesity. Nutr Res. 1999;19(1):85-101.

126. Prins JB, O'Rahilly S. Regulation of adipose cell number in man. Clin Sci. 1997;92(1):3-11.

127. Despres J, Bouchard C, Savard R, Tremblay A, Marcotte M, Theriault G. The effect of a 20-week endurance training program on adipose-tissue morphology and lipolysis in men and women. Metabolism. 1984;33(3):235-39.

128. Rajmil O, Puig-Domingo M, Tortosa F, et al. Melatonin concentration before and during testosterone replacement in primary hypogonadic men. Eur $\mathrm{J}$ Endocrinol. 1997;137:48-52.

129. Luboshitzky R, Wagner $\mathrm{O}$, Lavi S, Herer $\mathrm{P}$, Lavie $\mathrm{P}$. Abnormal melatonin secretion in male patients with hypogonadism. J Mol Neurosci. 1996;7(2):91-8.

130. Heideman PD, Bierl CK, and Sylvester CJ. Photoresponsive Fischer 344 Rats are reproductively inhibited by melatonin and differ in 2-[125I] lodomelatonin binding from nonphotoresponsive Sprague-Dawley rats. J Neuroendocrinol. 2001;13(3):22332.

131. Rudeen PK. Apparent dualistic effects of twice daily melatonin administration on reproductive organs in male golden hamsters. Horm Res. 1981;15(2):99-108.

132. Katznelson L, Finkelstein JS, Schoenfeld DA, Rosenthal DI, Anderson EJ, Klibanski A. Increase in bone density and lean body mass during testosterone administration in men with acquired hypogonadism. J Clin Endocrinol Metab. 1996; 81:4358-65.

133. Grinspoon S, Corcoran C, Lee K, et al. Loss of lean body and muscle mass correlates with androgen levels in hypogonadal men with acquired immunodeficiency syndrome and wasting. J Clin Endocrinol Metab.1996;81:4051-8.

134. Mauras $\mathrm{N}$, Hayes $\mathrm{V}$, Welch $\mathrm{S}$, et al. Testosterone deficiency in young men: marked alterations in whole body protein kinetics, strength, and adiposity. J. Clin. Endocrinol. Metab. 1998;83:1886-92.

135. Oner J, Oner H, Sahin Z, Demir R, Ustunel I, 2008. Melatonin is as effective as testosterone in the prevention of soleus muscle atrophy induced by castration in rats. Anat Rec (Hoboken). 2008;291:448-55. 
136. Frost RA, Lang $\mathrm{CH}$. Protein Kinase B/ Akt: A Nexus of Growth Factor and Cytokine Signaling in Determining Muscle Mass. J Appl Physiol. 2007;103:378-87.

137. Shima T, Chun SJ, Niijima A, et al. Melatonin suppresses hyperglycemia caused by intracerebroventricular injection of 2-deoxy-d-glucose in rats. Neurosci Lett. 1997;226:119-22.

138. Ha E, Yim SV, Chung JH, et al. Melatonin stimulates glucose transport via insulin receptor substrate-1/phosphatidylinositol 3-kinase pathway in C2C12 murine skeletal muscle cells. J Pineal Res. 2006;4:67-72.

139. Lima FB, Matsushita $\mathrm{DH}$, Hell NS, et al. The regulation of insulin action in isolated adipocytes. Role of the periodicity of food intake, time of day and melatonin. Braz J Med Biol Res. 1994;27:995-1000.

140. Ha E, Yim SV, Chung JH et al. Melatonin stimulates glucose transport via insulin receptor substrate-1/phosphatidylinositol 3-kinase pathway in C2C12 murine skeletal muscle cells. J Pineal Res. 2006;41:67-72.

141. Bodkin NL, Nicolson M, Ortmeyer HK, Hansen BC Hyperleptinemia: relationship to adiposity and insulin resistance in the spontaneously obese rhesus monkey. Horm Metab Res. 1996;28:674-8.

142. Wolden-Hanson T, Marck BT, Smith L, Matsumoto AM. Cross-sectional and longitudinal analysis of age-associated changes in body composition of male Brown Norway rats: association of serum leptin levels with peripheral adiposity. J Gerontol A Biol Sci Med Sci. 1999;54:B99-107.

143. Ríos-Lugo MJ, Cano $P$, Jiménez-Ortega $V$, et al. Melatonin effect on plasma adiponectin, leptin, insulin, glucose, triglycerides and cholesterol in normal and high fat-fed rats. J J Pineal Res. 2010;49(4):342-8.

144. Fruhbeck G, Gomez-Ambrosi J, Muruzabal FJ, Burrell MA. The adipocyte: a model for integration of endocrine and metabolic signaling in energy metabolism regulation. Am J Physiol Endocrinol Metab. 2001;280:E827-47.

145. Wahlen K, Sjölin E, Löfgren P. Role of fat cell size for plasma leptin in a large population based sample. Exp Clin Endocrinol Diabetes. 2011;119(5):291-4.

146. Kannan V. Diet, activity and diabetes. J Assoc Physicians India. 1999;47(8):761-3.

147. Rigla M, Sánchez-Quesada JL, Ordóñez-Lianos J, et al. Effect of physical exercise on lipoprotein (a) and low-density lipoprotein modifications in type-1 and type-2 diabetic patients. Metabolism. 2000;49(5):640-7.

148. Cheik NC, Guerra RLF, Viana FP, et al. Efeito de diferentes freqüéncias de exercício físico na prevencao da dislipidemia e da obesidade em ratos normo e hipercolesterolémicos. Rev bras Educ Fís Esp. 2006;20(2):121-9. 
149. Bojková B, Orendás $\mathrm{P}$, Friedmanová $\mathrm{L}$, et al. Prolonged melatonin administration in 6-month-old Sprague-Dawley rats: metabolic alterations. Acta Physiol Hung. 2008;95(1):65-76.

150. Ha E, Yim SV, Chung JH, et al. Melatonin stimulates glucose transport via insulin receptor substrate-1/phosphatidylinositol 3-kinase pathway in C2C12 murine skeletal muscle cells. J Pineal Res. 2006;41(1):67-72.

151. Lafontan $\mathrm{M}$, Berlan $\mathrm{M}$. Fat cell adrenergic receptors and the control of white and brown fat cell function. J Lipid Res. 1993;34:1057-91.

152. Lladó I, Rodríguez-Cuenca S, Pujol E, et al. Gender effects on adrenergic receptor expression and lipolysis in white adipose tissue of rats. Obes Res. 2002;10(4):296-305.

153. Carey GB. Mechanisms regulating adipocyte lipolysis. Adv Exp Med Biol. 1998;441:157-70.

154. Valet P, Grujic D, Wade J, et al. Expression of human alpha 2-adrenergic receptors in adipose tissue of beta 3-adrenergic receptor-deficient mice promotes diet-induced obesity. J BiolChem. 2000;275:34797-802.

155. Lafontan M, Berlan ML. Fat cell alpha 2-adrenoceptors: the regulation of fat cell function and lipolysis. Endocr Rev.1995;16:716 -38.

156. Zalatan F, Krause JA, Blask DE. Inhibition of isoproterenol-induced lipolysis in rat inguinal adipocytes in vitro by physiological melatonin via a receptor-mediated mechanism. Endocrinology. 2001;142(9):3783-90.

157. Large V, Reynisdottir S, Langin D, et al. Decreased expression and function of adipocyte hormone-sensitive lipase in subcutaneous fat cells of obese subjects. J Lipid Res. 1999;40(11):2059-66.

158. Arner P. Regulation of lipolysis in fat cells. Diabetes Rev. 1996;4:450-63.

159. Enevoldsen LH, Stallknecht B, Langfort $\mathrm{J}$ et al. The effect of exercise training on hormone-sensitive lipase in rat intra-abdominal adipose tissue and muscle. J Physiol 2001;536:871-7.

160. Izawa T, Komabayashi $\mathrm{T}$, Shinoda $\mathrm{K}$ et al. Possible mechanism of regulating adenylate cyclase activity in adipocyte membranes from exercise-trained male rats. Biochem Biophys Res Commum. 1988; 151:1262-68.

161. Shepherd RE, Noble EG, Klug GA et al. Lipolysis and cAMP accumulation in adipocytes in response to physical training. J Appl Physiol. 1981;50:143-8.

162. Enevoldsen LH, Stallknecht B, Fluckey JD, Galbo H. Effect of exercise training on in vivo lipolysis in intra-abdominal adipose tissue in rats Am J Physiol Endocrinol Metab. 2000;279:E585-92. 
163. Beylot M, Neggazi S, Hamlat N, Langlois D, Forcheron F. Perilipin 1 ablation in mice enhances lipid oxidation during exercise and does not impair exercise performance. Metabolism. 2012;61(3):415-23.

164. Stich V, de Glisezinski I, Crampes F, et al. Activation of antilipolytic alpha(2)adrenergic receptors by epinephrine during exercise in human adipose tissue. Am J Physiol. 1999;277:R1076-083.

165. Terrón MP, Delgado-Adámez J, Pariente JA, Barriga C, Paredes SD, Rodríguez AB. Melatonin reduces body weight gain and increases nocturnal activity in male Wistar rats. Physiol Behav. 2013;13:118:8-13. 